\title{
KEPEMILIKAN MANAJERIAL, KEBIJAKAN DIVIDEN, LEVERAGE, PROFITABILITAS, UKURAN PERUSAHAAN, DAN NILAI PERUSAHAAN (STUDI PADA PERUSAHAAN PERTAMBANGAN DI INDONESIA)
}

\author{
Dian Marhaeningtyas \\ Universitas Negeri Surabaya \\ dianmarhaeningtyas16080574097@mhs.unesa.ac.id \\ Ulil Hartono \\ Universitas Negeri Surabaya \\ ulilhartono@unesa.ac.id
}

\begin{abstract}
This study aims to examine and understand the effect of managerial ownership, dividend policy, leverage, profitability, and company size on the value of the mining sector listed on the Indonesia Stock Exchange period 2015-2018. This type of research is causal research and the data is quantitative sourced from the IDX web. The sampling method uses purposive sampling to obtain 16 companies that fit the criteria. Data analysis uses multiple linear regression. The test results explained that the independent variables simultaneously influence the dependent variable. Partial test results explain that leverage has a positive effect on firm value because the company's ability to pay obligations in the future will get a positive response from the market. Profitability has a positive effect on firm value because the increase in profits shows the company's ability to use its resources. The results of this study indicate that leverage and profitability have a significant positive effect on a firm's value, while managerial ownership, dividend policy, and firm size has no significant effect on a firm's value.
\end{abstract}

Keywords: dividend policy; firm size; leverage; managerial ownership; profitability.

\section{PENDAHULUAN}

Sejak awal mula berdirinya suatu perusahaan, para pemimpin perusahaan telah mengemukakan beberapa maksud dan harapan yang hendak diraih perusahaan tersebut. Mendapatkan laba yang maksimal merupakan tujuan utama suatu perusahaan didirikan, sedangkan tujuan kedua perusahaan yaitu untuk menyejahterakan para pemegang saham. Kemudian, tujuan perusahaan yang terakhir yaitu menaikkan harga saham di mana ketika harga saham suatu perusahaan terus mengalami kenaikan dapat mencerminkan bahwa perusahaan tersebut telah berhasil memaksimalkan nilai perusahaannya (Sukirni, 2012).

Para pemegang saham akan mendapatkan keuntungan ketika perusahaan memaksimalkan nilai perusahaannya. Artinya, para pemegang saham akan bertambah sejahtera ketika nilai saham suatu perusahaan meningkat, sebaliknya pemegang saham akan mendapatkan kerugian apabila nilai saham mengalami penurunan (Brigham \& Houston, 2014:8). Informasi perihal penilaian saham sungguh diperlukan para investor/ masyarakat sebagai pertimbangan untuk menentukan perusahaan sebelum menanamkan modalnya dan melakukan investasi di pasar modal. Tingginya nilai perusahaan mencerminkan kinerja perusahaan saat ini sehingga dapat membuat pasar percaya pada prospek perusahaan mendatang (Sihotang \& Saragih, 2017).

Rasio keuangan yang digunakan untuk mengukur tingkat besarnya nilai perusahaan pada penelitian ini yakni Price to Book Value (PBV), yang mana rasio ini membandingkan nilai buku suatu saham atas harga pasar saham tersebut. Terdapat beberapa pertimbangan memilih rasio PBV untuk membuat keputusan dalam berinvestasi, antara lain yaitu nilai buku mempunyai skala intuitif yang konstan sehingga dapat digunakan untuk membandingkan antara nilai buku atas harga pasarnya. Pertimbangan kedua yakni semua perusahaan mempunyai standar akuntansi yang tetap/konsisten pada nilai bukunya, sehingga PBV mampu memberikan petunjuk adanya undervaluation atau overvaluation di setiap perusahaan-perusahaan yang sama. Alasan ketiga adalah price book value ratio dapat digunakan untuk mengevaluasi perusahaan yang memiliki earning negatif (Kusumajaya, 2011). 


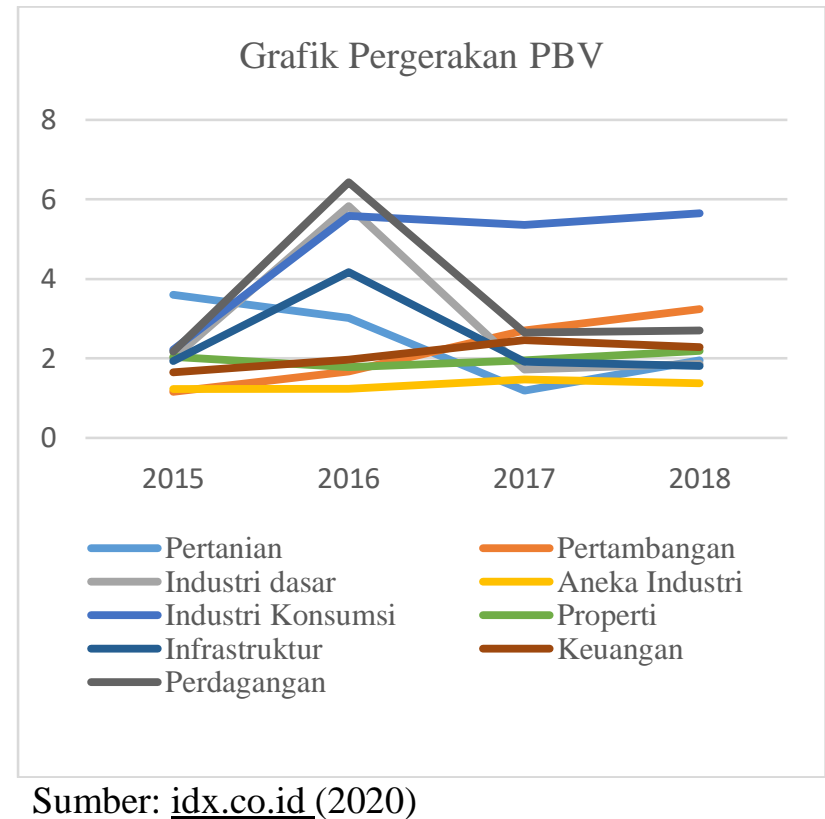

\section{Gambar 1. GRAFIK PERKEMBANGAN PBV SEKTORAL TAHUN 2015-2018}

Gambar 1 menjelaskan bahwa nilai PBV di sektor pertambangan adalah satu-satunya sektor yang naik secara terus-menerus, sedangkan delapan lainnya yang ada di Bursa Efek Indonesia dari tahun 20152018 mengalami pergerakan secara fluktuatif. Hal ini ditunjukkan pada nilai PBV sektor tambang sebesar 1,16 pada tahun 2015 dan diakhiri sebesar 3,24 di tahun 2018. Sejak awal 2016, indeks saham sektor tambang mengalami kenaikan yakni 53,35\%. Naiknya harga saham sektor tambang ini disebabkan harga minyak dunia yang mulai membaik (Rahmayanti, 2016). Badan Pusat Statistik (BPS) mencatat sektor pertambangan berhasil tumbuh 1,06 persen dari sebelumnya anjlok $7,91 \%$ pada periode yang sama tahun 2015. Pertumbuhan sektor pertambangan disebabkan oleh adanya kenaikan harga komoditas tambang yang juga membantu sektor ini tumbuh positif (Setyowati, 2017).

Salah satu faktor yang dapat memengaruhi nilai perusahaan adalah kepemilikan manajerial, di mana pihak manajemen sebagai pemilik perusahaan untuk ikut dilibatkan dalam pengambilan keputusan perusahaan yang bersangkutan (Fikriyan, 2019). Berdasarkan penelitian yang telah dilakukan oleh Sukirni (2012) dan Abdolkhani \& Jalali (2013), kepemilikan manajerial memengaruhi nilai perusahaan secara negatif. Namun penelitian tersebut tidak selaras dengan penelitian Pasaribu \& Sulasmiyati (2016) yang mengatakan bahwa kepemilikan manajerial memengaruhi nilai perusahaan secara positif. Hal ini berbeda dengan Adam (2014), yang menyatakan bahwa kepemilikan manajerial tidak memengaruhi nilai perusahaan.

Faktor selanjutnya yang memengaruhi nilai perusahaan adalah kebijakan dividen (Ismawati, 2018). Menurut Sihotang \& Saragih (2017) kebijakan dividen menjadi faktor yang memengaruhi nilai perusahaan karena pembagian dividen kepada investor akan memberikan sinyal yang baik pada perusahaan sehingga akan menarik minat investor untuk membeli saham perusahaan. Ismawati (2018), Fikriyan (2019), dan Pasaribu \& Sulasmiyati (2016) menyatakan bahwa kebijakan dividen memengaruhi nilai perusahaan secara positif, tetapi berbeda dengan temuan penelitian yang dilakukan oleh Sukini (2012) dan Herawati (2013) yang mengatakan bahwa kebijakan dividen tidak berpengaruh terhadap nilai perusahaan.

Leverage menjadi salah satu faktor yang memengaruhi nilai perusahaan (Chang \& Tzeng, 2011). Menurut Sudana (2011), melalui rasio ini dapat diketahui proporsi dana yang bersumber dari utang untuk membiayai aktiva perusahaan. Semakin besar rasio maka menunjukkan bahwa semakin besar porsi penggunaan utang dalam membiayai investasi pada aktiva, yang berarti pula risiko keuangan perusahaan meningkat dan sebaliknya. Penelitian yang dilakukan oleh Siahaan (2013), Prasetyorini (2013), Herawati (2013), dan Sihotang \& Saragih (2017), menyatakan bahwa leverage tidak 
Dian Marhaeningtyas \& Ulil Hartono. Kepemilikan Manajerial, Kebijakan Dividen, Leverage, Profitabilitas, Ukuran Perusahaan, dan Nilai Perusahaan (Studi pada Perusahaan Pertambangan di Indonesia)

berpengaruh terhadap nilai perusahaan. Namun lain dengan yang disampaikan Chang \& Tzeng (2011), Sukini (2012), Rudangga \& Sudiarta (2016), dan Fikriyan (2019) yang mengatakan bahwa leverage memengaruhi nilai perusahaan secara positif.

Menurut Kasmir (2012), profitabilitas merupakan rasio untuk menilai kemampuan perusahaan dalam mencari keuntungan. Rasio ini penting bagi pihak pemegang saham untuk mengetahui efektivitas dan efisiensi pengelolaan modal sendiri yang dilakukan oleh pihak manajemen perusahaan. Semakin tinggi rasio ini berarti semakin efisien penggunaan modal sendiri yang dilakukan oleh pihak manajemen perusahaan (Rudangga \& Sudiarta, 2016). Hal ini didukung oleh penelitian Hasbi (2015), Prasetyorini (2013), Rudangga \& Sudiarta (2016), Widyantari \& Yadnya (2017), Adam (2014), dan Sihotang \& Saragih (2017) yang menyatakan bahwa profitabilitas memengaruhi nilai perusahaan secara positif. Berbeda dengan penelitian Hirdinis (2019) yang mengatakan bahwa profitabilitas tidak memengaruhi nilai perusahaan. Hasil lain yaitu penelitian oleh Herawati (2013) yang mengatakan profitabilitas memengaruhi nilai perusahaan secara negatif.

Ukuran perusahaan ialah faktor yang memengaruhi nilai perusahaan (Siahaan, 2013). Menurut Rudangga \& Sudiarta (2016) nilai perusahaan yang meningkat dapat ditandai dengan total aktiva perusahaan yang mengalami kenaikan dan lebih besar dibandingkan dengan jumlah hutang perusahaan. Hal tersebut sesuai dengan penelitian yang dilakukan oleh Siahaan (2013), Prasetyorini (2013), dan Prasetya et al. (2014), yang mengatakan bahwa ukuran perusahaan memengaruhi nilai perusahaan secara positif. Hasil berbeda ditunjukkan oleh penelitian Pantow et al. (2015) dan Widyantari \& Yadnya (2017), yang menyatakan bahwa ukuran perusahaan tidak berpengaruh terhadap nilai perusahaan. Berbeda dengan penelitian yang dilakukan oleh Hirdinis (2019) dan Fikriyan (2019) yang menyebutkan bahwa ukuran perusahaan memengaruhi nilai perusahaans secara negatif.

Penelitian ini bertujuan untuk mengetahui pengaruh kepemilikan manajerial, kebijakan dividen, leverage, profitabilitas, serta ukuran perusahan terhadap nilai perusahaan sektor pertambangan periode 2015-2018.

\section{KAJIAN PUSTAKA DAN PENGEMBANGAN HIPOTESIS}

\section{Agency Theory}

Agency theory yakni suatu kondisi di mana pemegang saham mempekerjakan atau menyewa agen / seorang profesional untuk menjalankan tugas perusahaan dan pendelegasian dalam pengambilan keputusan yang menyangkut kepentingan agen. Jensen dan Meckling mengemukakan bahwa ada satu upaya yang dapat dilakukan supaya pihak manajemen berperan sejalan dengan kepentingan pemilik perusahaan, yaitu pemilik harus menjamin pihak manajemen membuat keputusan optimal hanya ketika diberi intensif yang memadai dan ketika manajemen merupakan pihak yang minoritas (Pasaribu \& Sulasmiyati, 2016).

\section{Bird in the Hand Theory}

Bird in hand theory memaparkan bahwa kebijakan dividen memberikan pengaruh positif atas harga pasar saham. Dengan kata lain, apabila dividen yang dibagi perusahaan bertambah besar, maka harga pasar saham perusahaan itu menjadi bertambah tinggi, sebaliknya semakin kecil dividen yang dibagi perusahaan maka semakin rendah pula harga sahamnya. Hal ini disebabkan pembagian dividen mampu menekan ketidakpastian yang dialami investor (Sudana, 2011:169).

\section{Signaling Theory}

Signaling theory menjelaskan bahwa pihak yang mempunyai banyak informasi mengenai kondisi perusahaan dan prospek perusahaan mendatang adalah pihak-pihak internal. Selain itu pihak internal juga mempunyai kelebihan penguasaan informasi dibandingkan dengan pihak eksternal perusahaan. Signaling theory berguna menggambarkan tingkah laku saat kedua pihak (individu dan organisasi) mempunyai akses atas informasi yang tidak sama (Gumanti, 2017:249). Selain itu signaling theory 
dapat memberikan informasi tentang tanda-tanda kebijakan perusahaan go public, di mana tanda itu dapat menjadi acuan oleh investor sebelum mengambil keputusan investasi (Umam \& Hartono, 2019).

\section{Nilai Perusahaan}

Nilai perusahaan dideskripsikan sebagai nilai wajar perusahaan yang mencerminkan persepsi/pandangan para investor kepada emiten terkait. Perusahaan yang memiliki kinerja yang baik dan mampu menghasilkan laba/keuntungan yang besar, maka nilai saham perusahaan itu otomatis akan tinggi pula (Fajaria, 2015). Nilai perusahaan pada penelitian diproksikan dengan price to book value (PBV), di mana harga pasar per saham perusahaan akan dibandingkan dengan nilai bukunya sebagai acuan dalam mengambil keputusan berinvestasi. Menurut Sihotang \& Saragih (2017) harga pasar per saham menjadi harga yang disetujui penjual dan pembeli ketika berlangsungnya transaksi per lembar saham. Sedangkan nilai buku per saham menjadi nilai historis per lembar saham atau harga ketika aktiva tersebut diperoleh. Formula dari PBV diuraikan di rumus (1). Sedangkan, nilai buku per lembar saham dihitung dari rumus (2) (Brigham\&Houston, 2014:152).

PBV $=\frac{\text { Harga Pasar Per Lembar Saham }}{\text { Nilai Buku Per Lembar Saham }}$

Nilai Buku $=\frac{\text { Total Ekuitas }}{\text { Jumlah Saham Beredar }}$

\section{Kepemilikan Manajerial}

Kepemilikan manajerial yakni komposisi/ persentase saham perusahaan yang dipegang pihak manajemen, direksi, komisaris, serta pihak yang turut andil/berkontribusi dalam pengambilan keputusan di perusahaan. Meningkatnya kepemilikan manajerial ialah salah satu cara yang dapat digunakan supaya kepentingan pemilik dengan manajer menjadi sejajar, sehingga dapat meminimalisir terjadinya konflik keagenan (Adam, 2014). Kusumaningtyas \& Andayani (2015) menyebutkan bahwa nilai perusahaan dapat dipengaruhi besar kecilnya tingkat kepemilikan manajerial di suatu perusahaan. Pada saat presentase kepemilikan manajerial tinggi/besar maka pihak manajemen otomatis berusaha meningkatkan kinerjanya demi kesejahteraan investor, sebaliknya ketika presentase kepemilikan manajerial kecil/rendah maka kinerja pihak manajemen akan cenderung menurun diikuti dengan menurunnya nilai perusahaan. Kepemilikan manajerial dalam laporan keuangan perusahaan ditunjukkan oleh presentase saham perusahaan yang dimiliki oleh manajer (Kautsar, 2019). Menurut Azzahrah \& Yuliandhari (2014), rumus kepemilikan manajerial diuraikan di rumus (3).

Kepemilikan Manajerial $=\frac{\text { Kepemilikan Saham Manajerial }}{\text { Total Saham yang Beredar }}$

\section{Kebijakan Dividen}

Dividen adalah jumlah pendapatan yang didistribusikan di antara pemegang saham perusahaan. Dengan kata lain dividen adalah distribusi sisa laba bersih perusahaan yang didistribusikan kepada pemegang saham, dengan persetujuan RUPS. Menurut Kautsar (2019), kebijakan dividen merupakan keputusan perusahaan mengenai keuntungan yang diperoleh perusahaan apakah akan dibagikan dengan pemegang saham atau disimpan dalam bentuk laba ditahan untuk investasi perusahaan mendatang. Menurut Rizqia et al. (2013) ada dua jenis pembagian dividen yakni dividen saham dan dividen tunai. Dividen saham tidak berpengaruh pada kekayaan pemegang saham kecuali hilangnya biaya transaksi yang terkait dengan saham (Kautsar, 2019). Para investor lebih menyukai dividen bentuk tunai sehingga banyak perusahaan yang membagikan dividen dalam bentuk tunai karena menjadi daya tarik investor dan dapat meningkatkan nilai perusahaan. Kebijakan dividen dalam penelitian ini menggunakan variabel dummy, di mana angka 0 (nol) sebagai simbol perusahaan yang tidak membagikan dividen secara tunai dan angka 1 (satu) sebagai simbol perusahaan yang membagikan dividen secara tunai (Ramadhany \& Purwohandoko, 2020).

\section{Leverage}


Dian Marhaeningtyas \& Ulil Hartono. Kepemilikan Manajerial, Kebijakan Dividen, Leverage, Profitabilitas, Ukuran Perusahaan, dan Nilai Perusahaan (Studi pada Perusahaan Pertambangan di Indonesia)

Leverage / tingkat hutang perusahaan mencerminkan besarnya kewajiban perusahaan dan modal pada pihak ketiga yang belum terbayar, di mana utang ini ialah sumber dana atau dikatakan modal perusahaan yang diperoleh melalui kreditor. Pembiayaan kebutuhan dana yang digunakan oleh perusahaan salah satunya bersumber dari hutang atau biasa disebut dengan pembiayaan eksternal (Sihotang \& Saragih, 2017). Rasio leverage dapat memberikan informasi mengenai jumlah dana eksternal/ yang disediakan peminjam dan jumlah dana internal/ pemilik perusahaan. Secara sederhana, rasio leverage digunakan untuk mengerti setiap rupiah modal sendiri yang menjadi jaminan utang (Kasmir, 2012:157). Leverage dapat diukur melalui rumus (4) sebagai berikut (Kasmir, 2012:158)

DER $=\frac{\text { Total Debt }}{\text { Total Equity }}$

\section{Profitabilitas}

Profitabilitas digunakan sebagai pembanding komponen yang tersedia di annual report perusahaan, khususnya laporan neraca keuangan dan laba rugi. Pengukuran profitabilitas mampu diukur untuk beberapa rentang waktu operasi, supaya dapat memperlihatkan perkembangan perusahaan tersebut baik kenaikan maupun penurunan, selain itu juga mencari penyebab adanya perubahan tersebut (Kasmir, 2012:196). Profitabilitas pada penelitian ini memilih proksi ROE (Return On Equity) di mana tingginya nilai ROE mencerminkan kemampuan perusahaan secara efektif dalam memanfaatkan sumberdaya yang dimiliki, sehingga semakin tinggi ROE maka akan diikuti naiknya nilai perusahaan. ROE adalah rasio perbandingan antara laba setelah pajak dengan modal sendiri atau modal saham yang digunakan untuk mengukur tingkat pengembalian atas investasi bagi pemegang saham biasa atau pemilik modal (Purwohandoko \& Asandimitra, 2006). Menurut Prasetyorini (2013) ROE dapat dirumuskan di rumus (5) sebagai berikut.

$\mathrm{ROE}=\frac{\text { Earning After } \text { Taxes }}{\text { Total Equity }}$

\section{Ukuran Perusahaan}

Jumlah aset, total penjualan, rata-rata total penjualan, dan rata-rata jumlah aktiva yang dimiliki oleh suatu perusahaan dapat dijadikan sebagai tolok ukur untuk menggolongkan perusahaan tersebut termasuk dalam kriteria perusahaan berukuran kecil, sedang, atau besar. Ketika jumlah aktiva perusahaan naik dan angkanya lebih besar dari total utang perusahaan, maka perusahaan tersebut dikatakan berhasil meningkatkan nilai perusahaannya (Prasetyorini, 2013). Perusahaan dikatakan mempunyai prospek yang baik untuk beberapa periode kedepan apabila perusahaan tersebut memiliki arus kas positif dan hal ini sering dialami perusahaan dengan jumlah aset yang besar. Dengan kata lain, perusahaan yang memiliki aset yang besar dianggap lebih stabil dan dapat meraup laba/keuntungan maksimal (Siahaan, 2013). Menurut Prasetyorini (2013), untuk menghitung ukuran perusahaan diformulakan di rumus (6) sebagai berikut.

Ukuran Perusahaan $=$ Ln Total Aset

\section{Hubungan antar Variabel}

Adam (2014) menjelaskan apabila semakin terkonsentrasi kepemilikan saham oleh pihak manajerial dapat meningkatkan pengendalian yang efektif terhadap kebijakan-kebijakan yang diambil oleh manajemen perusahaan yang akan memengaruhi besarnya nilai perusahaan. Kepemilikan saham oleh pihak manajerial memengaruhi kinerja manajemen dalam mengoptimalkan perusahaan, hal ini akan berpengaruh terhadap keberlangsungan hidup perusahaan (Pasaribu et al., 2016).

H1: Kepemilikan manajerial berpengaruh terhadap nilai perusahaan sektor pertambangan yang listing di BEI periode 2015-2018.

Besarnya dividen yang dibagikan kepada para pemegang saham akan menjadi daya tarik bagi pemegang saham karena sebagian investor cenderung lebih menyukai dividen dibandingkan dengan capital gain karena dividen bersifat lebih pasti. Banyaknya investor yang berinvestasi di perusahaan dapat 
menyebabkan meningkatnya harga saham sehingga dengan meningkatnya harga saham akan meningkatkan nilai perusahaan itu sendiri (Herawati, 2013).

H2: Kebijakan dividen berpengaruh terhadap nilai perusahaan sektor pertambangan yang listing di BEI periode 2015-2018.

Rudangga \& Sudiarta (2016) memaparkan bahwa leverage adalah gambaran dari pemakaian utang oleh suatu perusahaan untuk membiayai operasional perusahaan. Pengelolaan leverage sangatlah penting karena tingginya penggunaan leverage dapat meningkatkan nilai perusahaan.

H3: Leverage berpengaruh terhadap nilai perusahaan sektor pertambangan yang listing di BEI periode 2015-2018.

Adam (2014) menjelaskan apabila naiknya return on equity (ROE) dari tahun ke tahun pada perusahaan berarti terjadi adanya kenaikan laba bersih dari perusahaan yang bersangkutan. Naiknya laba bersih dapat dijadikan salah satu indikasi bahwa nilai perusahaan juga naik karena naiknya laba bersih sebuah perusahaan yang bersangkutan akan menyebabkan harga saham yang berarti juga kenaikan dalam nilai perusahaan.

H4: Profitabilitas berpengaruh terhadap nilai perusahaan sektor pertambangan yang listing di BEI periode 2015-2018.

Perusahaan yang besar lebih diminati dibandingkan dengan perusahaan kecil, sehingga pertumbuhan perusahaan sangat memengaruhi nilai perusahaan (Prasetya et al., 2014). Ukuran perusahaan yang besar juga menunjukkan bahwa perusahaan mengalami perkembangan sehingga investor akan merespon positif dan akan meningkat nilai perusahaan. Dengan semakin besar ukuran perusahaan, maka ada kecenderungan lebih banyak investor yang menaruh perhatian pada perusahaan tersebut (Widyantari \& Yadnya, 2017).

H5: Ukuran Perusahaan berpengaruh terhadap nilai perusahaan sektor pertambangan yang listing di BEI periode 2015-2018.

\section{METODE PENELITIAN}

Jenis penelitian ini yaitu penelitian kausalitas guna membuktikan adanya pengaruh variabel-variabel independen terhadap nilai perusahaan. Metode penelitian yang digunakan yakni metode kuantitiatif dan jenis data penelitian yakni data sekunder berupa annual report perusahaan sektor tambang periode 2015-2018 yang diperoleh melalui web idx.co.id. Perusahaan yang dijadikan populasi sebanyak 43 perusahaan dalam jangka waktu empat tahun, sedangkan metode pengambilan sampel ialah puposive sampling dengan menerapkan beberapa kriteria yang telah ditentukan hingga didapatkan 16 perusahaan sampel. Jumlah data telah didapat sebesar 64 sampel dan dirasa cukup untuk memenuhi syarat minimal yaitu 30 sampel. Penelitian ini menggunakan analisis yakni regresi linier berganda. Fase uji yang digunakan yaitu uji screening dan tranformasi data, uji asumsi klasik (normalitas, multikolinearitas, autokorelasi, dan heterokedastisitas), dan uji hipotesis (uji statistik F, uji statistik t, dan koefisien determinasi).

\section{HASIL DAN PEMBAHASAN}

\section{Hasil Uji Screening dan Transformasi Data}

Hasil One-Sample $K-S$ menunjukkan bahwa setelah dilakukan uji screening menunjukkan nilai asymp. sig. (2-tailed) sebesar 0,000 pada variabel nilai perusahaan, kepemilikan manajerial, kebijakan dividen, leverage, dan profitabilitas. Sedangkan untuk variabel ukuran perusahaan diperoleh nilai asymp. sig. (2-tailed) sebesar 0,27. Hasil tersebut berarti bahwa semua variabel belum terdistribusi secara normal. Oleh karena itu, perlu dilakukan transformasi data pada semua variabel dengan melihat bentuk grafik 
Dian Marhaeningtyas \& Ulil Hartono. Kepemilikan Manajerial, Kebijakan Dividen, Leverage, Profitabilitas, Ukuran Perusahaan, dan Nilai Perusahaan (Studi pada Perusahaan Pertambangan di Indonesia)

histogramnya agar dapat memenuhi asumsi normalitas (Ghozali, 2018:34). Transformasi data dilakukan dengan menerapkan model regresi SQRT untuk semua variabel independen dan dependen. Setelah melalui transformasi data dengan model SQRT semua variabel memperoleh hasil One-Sampel $K-S$ bahwa semua variabel baik independen maupun dependen telah terdistribusi normal, sehingga data tidak membutuhkan outlier.

\section{Hasil Uji Normalitas}

Hasil uji Kolmogorov-Smirnov memperlihatkan bahwa data terdistribusi secara normal dibuktikan oleh nilai signifikansi yang diperoleh sebesar 0,200 di mana angka tersebut lebih besar dari 0,05. Bukti lain ditunjukkan melalui hasil grafik histogram pada gambar 2 dan melalui gambar P-Plots pada gambar 3 berikut. Histogram memperlihatkan gambar yang serupa dengan garis lonceng sehingga menunjukkan bahwa data mempunyai distribusi yang normal. P-Plots memiliki titik yang memencar di daerah garis diagonal dan mengikuti arah garis diagonalnya, sehingga menunjukkan bahwa data mempunyai distribusi yang normal.

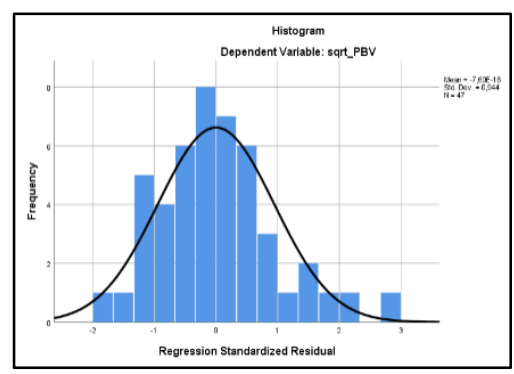

Sumber: Output SPSS (2020)

\section{Gambar 2. HISTOGRAM UJI NORMALITAS}

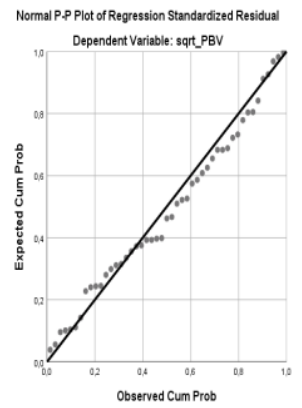

Sumber: Output SPSS (2020)

Gambar 3. NORMAL PROBABILITY PLOT

\section{Hasil Uji Multikolinearitas}

Hasil menunjukkan di mana tidak adanya gejala multikolinearitas antar variabel independen dalam penelitian ini karena didapatkan hasil nilai tolerance $>0,1$ pada semua variabel independen. Selain itu, didapatkan nilai VIF < 10 pada semua variabel independen yang mengindikasikan bahwa tidak adanya gejala multikolinearitas.

\section{Hasil Uji Autokorelasi}

Uji menunjukkan hasil Runs Test pada tabel 1 berikut diperoleh nilai Asymp. Sig. (2-tailed) 0,997 yang mana angka tersebut $>0,05$ yang artinya dalam penelitian ini tidak terdapat gejala autokorelasi atau bebas autokorelasi.

\section{Hasil Uji Heterokedastisitas}

Hasil uji spearman's rho memperlihatkan bahwa semua variabel mempunyai nilai sig. nya melebihi 0,05 maka penelitian ini dikatakan tidak timbul indikasi heterokedastisitas atau bebas multikolinearitas. 


\section{Tabel 1.}

HASIL UJI RUNS TEST

\begin{tabular}{lc}
\hline & Unstandardized Residual \\
\hline Test Value $^{\mathrm{a}}$ &,- 04795 \\
Cases $<$ Test Value & 23 \\
Cases $>=$ Test Value & 24 \\
Total Cases & 47 \\
Number of Runs & 25 \\
Z &, 003 \\
Asymp. Sig. (2-tailed) &, 997 \\
\hline
\end{tabular}

Sumber: Output SPSS (2020)

\section{Hasil Uji Regresi Linear Berganda}

Berdasarkan tabel 2, output regresi linier berganda berikut, dapat ditarik sebuah persamaan regresi (7) yakni berikut.

PBV $=0,299$ sqrt_DER $+1,275$ sqrt_ROE $+\mathrm{e}$

Tabel 2.

HASIL UJI REGRESI LINEAR BERGANDA

\begin{tabular}{llcccc}
\hline \multicolumn{1}{c}{ Model } & \multicolumn{2}{c}{ Unstandardized Coefficients } & & \\
& & B & Std. Error & t & Sig. \\
\hline 1 & (Constant) &,- 226 & 3,319 &,- 068 &, 946 \\
& sqrt_KEPMAN &, 422 &, 330 & 1,276 &, 209 \\
& sqrt_DER &, 299 &, 126 & 2,384 &, 022 \\
& sqrt_ROE & 1,275 &, 395 & 3,228 &, 002 \\
& sqrt_SIZE &, 115 &, 620 &, 186 &, 853 \\
& sqrt_KD &, 053 &, 163 &, 327 &, 745 \\
\hline
\end{tabular}

Sumber : Output SPSS (2020)

\section{Hasil Uji Statistik t}

Berdasarkan tabel 1 dapat dilihat bahwa variabel kepemilikan manajerial menghasilkan t-hitung 1,276 dan nilai signifikansi 0,209, di mana sig >0,05. Hasil ini memperlihatkan kepemilikan manajerial tidak mempunyai pengaruh pada nilai perusahaan. Hasil uji variabel yang kedua ialah kebijakan dividen menghasilkan t-hitung 0,327 dengan signifikansi 0,745 di mana sig >0,05. Hasil ini diartikan bahwa kebijakan dividen tidak memengaruhi nilai perusahaan. Hasil uji variabel ketiga yakni leverage menghasilkan t-hitung 2,384 dan sig. 0,022 di mana sig < 0,05. Hasil dapat diartikan leverage berpengaruh positif pada nilai perusahaan. Hasil uji variabel keempat adalah profitabilitas menghasilkan t-hitung 3,228 dan sig. 0,002 di mana sig < 0,05. Hasil dapat diartikan profitabilitas memengaruhi nilai perusahaan secara positif. Hasil uji variabel terakhir ialah firm size menghasilkan thitung 0,186 dan sig. 0,835 di mana sig >0,05. Hasil dapat diartikan firm size tidak berpengaruh pada nilai perusahaan.

\section{Hasil Uji Koefisien Determinasi}

Hasil uji menggunakan Adjusted $R^{2}$ diperoleh angka sebesar 0,385 yang memperlihatkan bahwa variabel independen memengaruhi variabel dependen sebesar $38,5 \%$. Sisanya $61,5 \%$ dijelaskan variabel lain di luar penelitian ini.

\section{Pengaruh Kepemilikan Manajerial terhadap Nilai Perusahaan}

Hasil uji riset ini memperlihatkan kepemilikan manajerial tidak memengaruhi nilai perusahaan. Hasil penelitian ini mendukung penelitian Adam (2014) yang mengatakan kepemilikan manajerial memengaruhi pada nilai perusahaan. Hasil tersebut dikarenakan ketika biaya monitoring suatu perusahaan semakin besar yang menyebabkan agency cost juga semakin tinggi, pihak manajerial yang minoritas tidak mempunyai wewenang untuk ikut andil dalam hal keputusan ekonomi dan kelangsungan 
Dian Marhaeningtyas \& Ulil Hartono. Kepemilikan Manajerial, Kebijakan Dividen, Leverage, Profitabilitas, Ukuran Perusahaan, dan Nilai Perusahaan (Studi pada Perusahaan Pertambangan di Indonesia)

hidup perusahaan sehingga pihak manajerial tidak dapat berperan terhadap kenaikan harga saham yang memengaruhi nilai perusahaan.

Hasil ini didukung data perusahaan PT. Bayan Resource tahun 2015 mempunyai nilai kepemilikan manajerial 0,516149 dan PBV 7,9. Sedangkan pada 2016 mempunyai nilai kepemilikan manajerial 0,649951 dan PBV naik 10,77. Dan tahun 2017 nilai kepemilikan manajerial naik menjadi 0,650176 namun nilai PBV justru turun menjadi 6,42. Sehingga berarti bahwa besar kecilnya presentase kepemilikan manajerial tidak memengaruhi nilai perusahaan.

Rata-rata kepemilikan manajerial pada seluruh perusahaan pertambangan yaitu sebesar 0,140 atau $14 \%$ saja. Dari data yang diperoleh diketahui bahwa ada 34 perusahaan dari 64 perusahaan sampel yang mempunyai nilai kepemilikan manajerial di bawah 5\%, yang mana menurut Adam (2015) proporsi kepemilikan manajerial yang ideal dalam suatu perusahaan adalah di atas $5 \%$ dari total saham yang beredar.

Implikasi teoritis penelitian ini tidak selaras dengan Agency theory yang mengatakan bahwa agency cost mampu diminimalisir/ menurun ketika presentase kepemilikan manajerial semakin besar sehingga akan meningkatkan nilai perusahaan. Menurut Adam (2014) tidak berpengaruhnya kepemilikan manajerial ini kemungkinan dikarenakan perusahaan pertambangan memiliki presentase kepemilikan manajerial yang relatif rendah atau dapat dikatakan di bawah 5\% sehingga pihak manajemen dan pemilik tidak dapat mensejajarkan kepentingannya dan akhirnya timbul konflik keagenan karena pihak manajemen tidak mempunyai informasi yang sebanding dengan pemilik. Implikasi praktis dari penelitian ini adalah pihak manajerial yang terlibat dalam pemungutan keputusan pada perusahaan pertambangan dirasa kurang efektif untuk dapat memantau kegiatan perusahaan sehingga tidak mampu mensejajarkan kepentingan investor juga manajemen dan tidak akan memengaruhi nilai perusahaan

\section{Pengaruh Kebijakan Dividen terhadap Nilai Perusahaan}

Hasil riset memperlihatkan bahwa kebijakan dividen tidak memengaruhi nilai perusahaan. Hasil ini didukung penelitian Herawati (2013) yang memaparkan bahwa investor hanya melihat total pengembalian (return) dari keputusan investasi, tanpa mempermasalahkan dari mana asal pengembalian tersebut entah dari capital gain atau dari dividen yang dibayarkan perusahaan. Sehingga keputusan mengenai laba yang dihasilkan akankah dibagikan bentuk dividen atau ditanamkan kembali di perusahaan tidak akan berdampak pada nilai perusahaan.

Data pendukung hasil riset diperlihatkan oleh perusahaan PT. Apexindo Pratama Duta tahun 2015-2018 tidak pernah membagikan dividen secara tunai namun terjadi kenaikan harga saham pada tahun 2016 dengan nilai PBV yang naik semula 9,3 menjadi 10,35. Sedangkan pada tahun 2018 harga saham turun dengan nilai PBV yang semula 8,62 turun menjadi -3,67. Sehingga berarti bahwa perusahaan membagikan dividen secara tunai maupun tidak membagikan dividen secara tunai tidak memengaruhi nilai perusahaan.

Rata-rata kebijakan dividen seluruh perusahaan pertambangan yaitu sebesar 0,30 atau 30\%. Dari data yang diperoleh diketahui bahwa terdapat 19 perusahaan dari total 64 perusahaan sampel yang tidak membagikan dividennya secara tunai. Hal ini berarti bahwa masih terdapat 19 perusahaan pertambangan yang menderita rugi dalam tahun buku berjalan sehingga tidak memungkinkan adanya pembagian dividen, yang mana idealnya pembagian dividen dalam suatu perusahaan yaitu sebesar $20 \%$ dari laba bersih yang diperoleh perusahaan.

Implikasi teoritis riset ini tidak selaras dengan Bird In Hand Theory yang memaparkan bahwa para investor cenderung mengharapkan pembagian dividen daripada capital gain di masa mendatang. Implikasi praktis penelitian ini yaitu pembagian dividen apakah secara tunai maupun non tunai tidak akan memengaruhi peningkatan nilai perusahaan pertambangan, selain itu tingginya /rendahnya dividen yang dibayarkan pada investor tidak ada kaitannya dengan tingginya /rendahnya nilai perusahaan. 


\section{Pengaruh Leverage terhadap Nilai Perusahaan}

Hasil riset memperlihatkan bahwa leverage memengaruhi nilai perusahaan secara positif. Hasil riset ini selaras dengan penelitian Rudangga \& Sudiarta (2016), yang mengatakan bahwa perusahaan yang telah melakukan kinerja dengan baik yakni ketika perusahaan tersebut telah melunasi seluruh hutang jangka panjangnya, dengan begitu akan tecipta nilai perusahaan yang baik pula.

Data pendukung hasil penelitian ini yaitu perusahaan Apexindo Pratama Duta Tbk. tahun 2015 memiliki DER 14,30 dan PBV 10,35. Pada tahun 2018 DER mengalami penurunan sebesar 9,3. Pada tahun 2016 DER perusahaan terus naik hingga sampai pada angka sebesar 24,30 serta diikuti naiknya nilai PBV hingga sebesar -4,43 dan diikuti dengan turunnya nilai PBV sebesar -3,67. Maka dari itu dapat diketahui bahwa leverage berpengaruh positif pada nilai perusahaan.

Implikasi teoritis riset ini selaras dengan signaling theory yang memaparkan apabila penggunaan hutang yang tinggi akan menaikkan nilai perusahaan. Implikasi praktis riset ini ialah dengan adanya penggunaan hutang di perusahaan pertambangan ternyata membawa dampak yang baik bagi peningkatan perusahaan. Perusahaan sektor pertambangan memerlukan dana dalam jumlah yang cukup banyak sehingga dengan berhutang dianggap cukup efektif untuk memenuhi likuiditas perusahaan, sehingga mampu beroperasi dengan baik dan nilai perusahaan meningkat.

\section{Pengaruh Profitabilitas terhadap Nilai Perusahaan}

Hasil penelitian ini memperlihatkan bahwa profitabilitas memengaruhi nilai perusahaan secara positif. Profitabilitas yang berpengaruh positif pada nilai perusahaan menurut Rudangga \& Sudiarta (2016) disebabkan perusahaan akan memiliki kecukupan dana ketika profitabilitas perusahaan tinggi, sehingga perusahaan dapat mengoptimalkan kinerjanya yang berdampak pada peningkatan laba. Tingginya tingkat profitabilitas perusahaan akan selalu diikuti dengan naiknya laba per lembar saham sehingga dengan adanya kenaikan laba per lembar saham dapat menarik para pemegang saham untuk menanamkan modalnya dan akan meningkatkan nilai perusahaan.

Data pendukung hasil penelitian ini ditujukkan perusahaan Adaro Energy Tbk., tahun 2015 dengan ROE 0,05 dan PBV 0,33. Tahun 2016 ROE naik 0,09 dan diikuti naiknya PBV 1,18. Tahun 2017 ROE menurun 0,08 dan diikuti dengan turunnya nilai PBV sebesar 1,09. Hal ini menjelaskan bahwa naiknya profitabilitas memengaruhi nilai perusahaan secara positif.

Implikasi teoritis riset ini selaras dengan signaling theory yang memaparkan bahwa pertumbuhan ROE mencerminkan prospek perusahaan yang lebih baik diketahui dari potensi kenaikan laba yang dihasilkan perusahaan. Implikasi praktisnya adalah dengan adanya peningkatan nilai ROE pada perusahaan pertambangan membawa dampak yang baik dalam meningkatkan nilai perusahaan dan perusahaan pertambangan telah mampu secara efektif dalam memanfaatkan sumberdaya yang dimiliki.

\section{Pengaruh Ukuran Perusahaan terhadap Nilai Perusahaan}

Hasil riset ini memperlihatkan bahwa ukuran perusahaan tidak memengaruhi nilai perusahaan. Hasil ini mendukung penelitian Widyantari \& Yadnya (2017) yang menyebutkan bahwa ukuran perusahaan yang besar tidak selalu diiringi peningkatan nilai perusahaannya.

Data pendukung penelitian ini ialah perusahaan PT. Adaro Energy tahun 2015 memiliki ukuran sebesar 32,04 dan nilai PBV 0,33. Sedangkan pada tahun 2016 memiliki ukuran sebesar 25,20 tetapi nilai PBV naik sebesar 1,18 . Sehingga dapat diketahui bahwa besar kecilnya proporsi ukuran perusahaan tidak berdampak pada nilai perusahaan.

Implikasi teoritis riset ini tidak selaras dengan signaling theory yang memaparkan bahwa perusahaan dengan pertumbuhan yang besar memberikan sinyal positif, karena perusahaan dengan pertumbuhan yang besar tidak akan kesulitan dalam memasuki pasar modal. Implikasi praktis penelitian ini yaitu perusahaan pertambangan tidak perlu menambah total aset untuk menaikkan nilai perusahaan, karena para pemegang saham akan melakukan penilaian baik buruknya perusahaan berdasarkan tinjauan 
Dian Marhaeningtyas \& Ulil Hartono. Kepemilikan Manajerial, Kebijakan Dividen, Leverage, Profitabilitas, Ukuran Perusahaan, dan Nilai Perusahaan (Studi pada Perusahaan Pertambangan di Indonesia)

menyeluruh atas aspek di perusahaan seperti tingkat penjualan, laporan keuangan perusahaan, citra perusahaan, dan lain-lain (Suwardika \& Mustanda, 2017).

\section{KESIMPULAN}

Variabel independen yang memengaruhi secara positif pada nilai perusahaan yaitu leverage dan profitabilitas. Sedangkan variabel independen yang tidak memengaruhi nilai perusahaan yaitu kepemilikan manajerial, kebijakan dividen, dan ukuran perusahaan. Sehingga semua perusahaan di sektor tambang dapat melakukan upaya untuk mempertahankan kenaikan PBV atau meningkatkan nilai perusahaan dengan cara lebih memperhatikan faktor kebijakan hutang dan juga faktor profitabilitas. Adanya peningkatan hutang dapat membantu perusahaan dalam membayar kewajiban dimasa mendatang, sedangkan profitabilitas yang tinggi dapat menaikkan nilai perusahaan.

Berdasarkan hasil riset ini penelitian berikutnya disarankan supaya memperbanyak variabel independen lain dalam memengaruhi nilai perusahaan seperti tingkat suku bunga, inflasi, kurs mata uang, dan variabel pengukuran yang lain. Selain itu penelitian selanjutnya juga disarankan untuk menambah periode riset yang lebih dari empat tahun supaya hasil diperoleh lebih maksimal dari riset ini.

\section{DAFTAR PUSTAKA}

Abdokhani, H., \& Jalali, R. (2013). Effect of managerial ownership concentrated on firm return and value: Evidence from Iran Stock Market. International Journal of Academic Research in Accounting, Finance and Management Sciences, 3(1), 46-51.

Adam, I. A. (2015). Pengaruh Struktur Kepemilikan, Struktur Modal, Profitabilitas dan Pertumbuhan Perusahaan Terhadap Nilai Perusahaan. Future: Jurnal Manajemen Dan Akuntansi, (2006), $102-114$.

Arshida, M. M. (2012). Critical Success Factors (CSFs) for TQM Implementation: Current Status and Challenges in Libyan Manufacturing Companies. GSTF Journal on Business Review, 2(1), 7179. https://doi.org/10.5176/2010-4804

Azzahrah, Z. dan, \& Yuliandhari, W. S. (2019). Pengaruh Mekanisme Good Corporate Governance Terhadap Nilai Perusahaan. Journal of Chemical Information and Modeling, 53(9), 1689-1699. https://doi.org/10.1017/CBO9781107415324.004

Brigham, E. F. \& Houston, J.F. (2014). Dasar - Dasar Manajemen Keuangan. Jakarta: Salemba Empat.

Budianto, W., \& Payamta, P. (2014). Pengaruh Kepemilikan Manajerial Terhadap Nilai Perusahaan Dengan Kebijakan Dividen Sebagai Variabel Moderasi. Assets: Jurnal Akuntansi Dan Pendidikan, 3(1). https://doi.org/10.25273/jap.v3i1.1207

Cheng, M.-C., \& Tzeng, Z.-C. (2011). The Effect of Leverage on Firm Value and How The Firm Financial Quality Influence on This Effect. World Journal of Management, 3(2), 30-53.

Fikriyan, A. A. (2019). Pengaruh Rasio Keuangan Dan Kebijakan Manajerial Terhadap Nilai Perusahaan Pada Sektor Pertambangan Yang Terdaftar Di Bei Periode 2015-2017. Jurnal Ilmu Manajemen (JIM), 7.

Gede Rudangga, I., \& Merta Sudiarta, G. (2016). Pengaruh Ukuran Perusahaan, Leverage, Dan Profitabilitas Terhadap Nilai Perusahaan. E-Jurnal Manajemen Universitas Udayana, 5(7).

Ghozali, I. (2018). Aplikasi Analisis Multivariet Dengan Program IBM SPSS 25. Ed. 9. Semarang: Badan Penerbit Universitas Diponegoro. 
Gumanti, T. A. (2017). Keuangan Korporat: Tinjauan Teori dan Bukti Empiris. Jakarta: Mitra Wacana Media.

Hasbi, H. (2015). Islamic Microfinance Institution: The Capital Structure, Growth, Performance and Value of Firm in Indonesia. Procedia - Social and Behavioral Sciences, 211, 1073-1080. https://doi.org/10.1016/j.sbspro.2015.11.143

Herawati, T. (2013). Pengaruh Kebijakan Dividen, Kebijakan Hutang Dan Profitabilitas Terhadap Nilai Perusahaan. Jurnal Manajemen, 2(02), Jurnal Man, 1-18.

Hirdinis, M. (2019). Capital Structure And Firm Size On Firm Value Moderated By Profitability. International Journal of Economics and Business Administration Volume VII, Issue 1, 7(1), 174191. https://doi.org/10.35808/ijeba/204

idx.co.id. (2019). Bursa Efek Indonesia. Retreived December 2, 2019, from www.idx.co.id

Ismawati, L. (2018). The Influence of Capital Structure and Dividens Policy to Firms Value Listed at Indonesian Stock Exchange. Advances in Social Science, Education and Humanities Research, Volume 225 International, 225(Icobest), 272-275. https://doi.org/10.2991/icobest-18.2018.59

Kasmir, D. (2012). Analisis Laporan Keuangan. Jakarta: PT Raja Grafindo Persada.

Kautsar, A. (2019). The Impact of Ownership Structure on Dividend Payout Property and Construction Companies in Indonesia. International Journal of Academic Research in Economics \& Management Sciences, 8(1), 66-74. https://doi.org/10.6007/IJAREMS/v8-i1/5555

Kusumajaya, D. K. O. (2011). Pengaruh Struktur Modal dan Pertumbuhan Perusahaan terhadap Profitabilitas dan Nilai Perusahaan pada Perusahaan Manufaktur di Bursa Efek Indonesia. Unpublished Thesis. Universitas Udayana, 1-132.

Muryati, N., \& Suardikha, I. (2014). Pengaruh Corporate Governance Pada Nilai Perusahaan. E-Jurnal Akuntansi, 9(2), 425-429.

Nurvianda, G., . Y., \& Ghasarma, R. (2019). Pengaruh Keputusan Investasi, Keputusan Pendanaan dan Kebijakan Dividen Terhadap Nilai Perusahaan. Jurnal Manajemen Dan Bisnis Sriwijaya, 16(3), 164-176. https://doi.org/10.29259/jmbs.v16i3.7380

Pasaribu, M. Y., \& Sulasmiyati, S. (2016). Pengaruh Struktur Modal, Struktur Kepemilikan Dan Profitabilitas Terhadap Nilai Perusahaan Pada Perusahaan Sektor Industri Dasar Dan Kimia Yang Terdaftar Di Bei Tahun 2011-2014. Jurnal Administrasi Bisnis S1 Universitas Brawijaya, 35(1), 154-164. Retrieved from https://media.neliti.com/media/publications/86967-ID-pengaruhstruktur-modal-struktur-kepemil.pdf

Purwohandoko \& Asandimitra. N. (2006). Manajemen Keuangan 1. Surabaya: Unesa University Press.

Rahmayanti, E. (2016). Indeks Sektor Pertambangan Menguat 53\% Sepanjang 2016, Penopang Utama IHSG?. Retreived March 5, 2020, from https://www.bareksa.com/id/text/2016/10/17/indekssektor-pertambangan-menguat-53-sepanjang-2016-penopang-utama-ihsg/14103/analysis

Ramadhany, A. D., \& Purwohandoko. (2020). Pengaruh Kebijakan Dividen, Dar, Firm Size Dan Roa Terhadap Nilai Perusahaan Sektor Consumer Good Yang Terdaftar Di Bei Periode 2013-2017. Jurnal Ilmu Manajemen (JIM), 8, 87-96.

Rizqia, D. A., Aisjah, S., \& Sumiati. (2013). Effect of Managerial Ownership , Financial Leverage , Profitability, Firm Size, and Investment Opportunity on Dividend Policy and Firm Value. 
Dian Marhaeningtyas \& Ulil Hartono. Kepemilikan Manajerial, Kebijakan Dividen, Leverage, Profitabilitas, Ukuran Perusahaan, dan Nilai Perusahaan (Studi pada Perusahaan Pertambangan di Indonesia)

Research Journal of Finance and Accounting, 4(11), 120-130.

Saerang, I., Tommy, P., \& Prasetia, T. E. (2014). Struktur Modal, Ukuran Perusahaan Dan Risiko Perusahaan Terhadap Nilai Perusahaan Otomotif Yang Terdaftar Di Bei. Jurnal Riset Ekonomi, Manajemen, Bisnis Dan Akuntansi, 2(2), 879-889.

Sanusi, A. (2011). Metodologi Penelitian Bisnis. Jakarta : Salemba Empat.

Sihotang, D. R., \& Saragih, J. L. (2017). Pengaruh Kebijakan Dividen, Kebijakan Utang Dan Profitabilitas Terhadap Nilai Perusahaan Pada Perusahaan Manufaktur Yang Terdaftar Di Bursa Efek Indonesia. Jurnal Riset Dan Akuntansi (JRAK), 3(1), 29.

Sari, P., \& Abundanti, N. (2014). Pengaruh Pertumbuhan Perusahaan Dan Leverage Terhadap Profitabilitas Dan Nilai Perusahaan. E-Jurnal Manajemen Universitas Udayana, 3(5), 43944422.

Setyowati, D. (2017). Sempat Terpuruk, Bisnis Tambang Mulai Bangkit di Akhir 2016. Retreived March 5, 2020, from https://katadata.co.id/berita/2017/02/06/terpuruk-di-2015-bisnispertambangan-mulai-bangkit-di-akhir-2016

Sudana, I. M. (2011). Manajemen Keuangan Perusahaan. Jakarta: Erlangga.

Sugiyono, P. D. (2017). Statistika untuk Penelitian. Bandung: Alfabeta.

Sukirni, D. (2012). Kepemilikan Manajerial, Kepemilikan Institusional, Kebijakan Deviden Dan Kebijakan Hutang Analisis Terhadap Nilai Perusahaan. Accounting Analysis Journal, 1(2). https://doi.org/10.15294/aaj.v1i2.703

Suwardika, I. N. A., \& Mustanda, I. K. (2017). Pengaruh Leverage, Ukuran Perusahaan, Pertumbuhan Perusahaan, Dan Profitabilitas Terhadap Nilai Perusahaan Pada Perusahaan Properti. E-Jurnal Manajemen Unud, 6(3), 12248-1277.

Trang, I., Murni, S., \& Pantow, M. S. (2015). Analisa Pertumbuhan Penjualan, Ukuran Perusahaan, Return on Asset, Dan Struktur Modal Terhadap Nilai Perusahaan Yang Tercatat Di Indeks Lq 45. Jurnal Riset Ekonomi, Manajemen, Bisnis Dan Akuntansi, 3(1), 961-971.

Umam, K. A., \& Hartono, U. (2019). Firm Size , Profitabilitas, Struktur Modal, Kebijakan Dividen, GCG, CSR, dan Nilai Perusahaan (Studi pada Perusahaan Sektor Finance di Bursa Efek Indonesia). Jurnal Ilmu Manajemen, 7, 642-654.

Widyantari, N. L. P. dan, \& Yadnya, I. P. (2017). Pengaruh Struktur Modal, Profitabilitas Dan Ukuran Perusahaan Terhadap Nilai Perusahaan Pada Perusahaan Food And Baverage Di Bursa Efek Indonesia. E-Jurnal Manajemen Unud, 6(12), 6383-6409. 